\title{
The Goodness and Truth-Analysis on the Thesis and Value of Iris Murdoch's Novels
}

\author{
Jiayuan Chen ${ }^{*}$, Jia Gao ${ }^{2}$ \\ ${ }^{1}$ Department of English, School of Foreign Languages, Northwest University, Xi'an, China \\ ${ }^{2}$ Department of English, School of Foreign Languages, Guizhou Normal University, Guiyang, China \\ Email: *violette.chen@foxmail.com
}

How to cite this paper: Chen, J. Y., \& Gao, J. (2019). The Goodness and Truth-Analysis on the Thesis and Value of Iris Murdoch's Novels. Advances in Literary Study, 7, 39-43.

https://doi.org/10.4236/als.2019.72005

Received: January 28, 2019

Accepted: March 30, 2019

Published: April 2, 2019

Copyright (c) 2019 by author(s) and Scientific Research Publishing Inc. This work is licensed under the Creative Commons Attribution International License (CC BY 4.0).

http://creativecommons.org/licenses/by/4.0/

\begin{abstract}
Iris Murdoch is a prolific female writer in the British contemporary literary world. In response to the spiritual and moral dilemma in the British society in the 1950s, Murdoch showed her concerns about egoists and society in her four early novels, trying the utmost to help those trapped in self-difficulties get out of trouble. From the perspective of existentialism, this paper is going to reveal the moral improvement process from firstly being ego to concern more with the needs and wishes of others via analyzing some excerpts of $U n$ der the Net (1954) and Against Dryness (1997), so as to demonstrate the common theme expressed by Murdoch-pursue genuine morality by caring about others. This paper will discuss the goodness and truth-analysis on the thesis and value of Iris Murdoch's novels.
\end{abstract}

\section{Keywords}

Iris Murdoch, Existentialism, Solipsism, The Goodness, Selflessness, Truth

\section{Introduction}

Iris Murdoch is one of the most influential novelists in the field of British literature after World War II and is also an ethical philosophy with a broad international reputation. She is known for her moral philosophy and novel creation. Since her first philosophy Sartre: Romantic Rationalist (1953), she has published nearly 40 books covering novels, plays and philosophy by 1997, among which 26 are novels. She is a rare prolific writer in British literature since Dickens. And, she had been pondering about various problems in novels in addition to philosophical speculation and literary creation. Her novel view echoes her overall philosophical and literary views and is committed to understanding and interpreting the two keywords "goodness" and "freedom". She had put unremitting 
efforts to help people seek the goodness and truth from art and moral literature.

\section{Discussion}

There are mainly two genres regarding British novels when Murdoch began to write novels in 1950s, among which one records the reality of the society and the other focuses on the reflection of the society. The former genre was dominant in the early age of 1950s to present the change of the British society after the war from the perspective of middle lower class as well as working class. Their works highlight philosophical narratives and the value of freedom (Hou \& He, 1998). In philosophy, they are mainly influenced by French philosophers with the idea of existentialism. All of them believe that modern industry would undermine the moral abilities because of the exploitation of labor and lead to unsound relationships. At that time, their work was often considered to be very modern and experimental (He, 2009).

Murdoch defined modern people as two types in her early works: ordinary people of empirical nature and totalitarian based on existentialism in English philosophy and French philosophy (Wu, 2008). In French literature, the most significant influence is Sartre's existentialism. Existential philosophy classifies the world as irrational, absurd and meaningless. Human beings are lost, struggling, seeking salvation and losing themselves. And the existence of human beings also becomes a joke as they lose their value. In her works, she discards the objective existence of human beings and goes directly into the innermost heart of human beings, the essence of human beings, and the morality. However, Murdoch also has some objections to Sartre's views such as "L'enfer, c'est les autres" (Hell is other people) (Shen, 2005). "The Other" is a form of reflection mechanism (i.e. from a phenomenological point of view, faith etc.) without independent personality. Sartre suspects everything in the universe, but only affirms the authenticity and value of existence. He said "There is no transcendental reality, no different degrees of freedom" (Xu et al., 1982)—human beings are defined as lonely individuals and are condemned to be free. In British philosophy, others are the will of loneliness or the will of freedom and reason. In Murdoch's work, such "other" modern person has also been mentioned: "He is rational and completely free". Morally, he is the monarch and examines everything and is completely responsible. Nothing can go beyond him (Wang, 2006) (Against Dryness. pp. 24-25). Murdoch believes that "others" should be treated as independent souls and independent personalities. This is the basis for pursuing beauty, morality, and love, and overemphasizing freedom as well as innate power would deny the self-will in the process of selection. The absolute freedom of mankind is not to despise others, to be completely self-centered and self-defining. These two philosophical concepts do not recognize the nature of human beings, but reduce and despise the value of human beings, and abandon the exploration of human beings. And she believes that these views tend to be Solipsism because the real world and the real society in which we really live are not simply black 
and white. It is full of diversities and to simply describe the relation between people and the world in philosophy should not be considered as scientific and complete. She emphasized that what we need is: "A set of solid theories about human nature which connects people as free and independent individuals, and is closely connected with the diverse world and all kinds of people together" (Wang, 2006). However, "we should no longer look at human beings beyond the perspective of human values but treat them as courageous and sincere ideas surrounded by an experiential world" (Wang, 2006). Murdoch said that we still don't have that kind of theory yet. Therefore, her works often focus on "human self-exploration" and "humanity analysis", emphasizing the particularity and individuality of human individuals, and acknowledging the existence of "selflessness" and "other consciousness".

In The Nice and the Good, she wrote: "The coupling disorder must be protected because it is the essence of human nature. It is important to remember the following two points: the fact that the novel is written by words and 'The hints and rhythm of fluency' illustrated by James. A novel is like a house, and suitable roles can live freely. It should respect the reality and its various coupling methods, and combine such reality with the perfect form-which should be considered as the highest level of prose art (Wittgenstein, 1992)". The characters in Murdoch's works are constantly fighting so that they can accept the disorder of life without the help of patterns or categories, such as Jake Donaghue in Under the Net. Under the Net is Murdoch's first novel, but it contains profound artistic thoughts and moral philosophical meaning (Yin, 1999). The novel mainly talks about the story of the hero Jake Donaghue in a few weeks. Jake is a native of Ireland, but grew up in London, who does not have a job and family and struggles to survive by translating French. After experiencing a series of bizarre events, he finally realized that his understanding of the world was absurd, and the real world and self-righteous life are not real. In the end, he was determined to return to his hometown and actually wrote his own work instead of translating for others. Judging from the nature of protagonist's action, there is no substantial change in the beginning of him being homeless and out of option and when he finally made the decision in the end. However, his worldview has undergone a fundamental change, and the will is completely different. This is what Murdoch wants to express-the spiritual sublimation and self-evolution brought about by the dynamic and spiritual power that people should have (Liu, 1985). In this process, Jake's spiritual growth can be seen from subjectively judging others, neglecting and denying others' potential to be selfless and seeking the power of the truth (Murdock, 1960). On the philosophical level, Jake became a man of virtue. At the same time, in Against Dryness, Murdoch also mentioned: "We are not the monarch who can change human beings, not people with independent choices. In fact, we are only living in our own world, subjectively. That is to say, we need to gradually wake up from a distorted mind, from the self-centered position to include others into the self" (Wang, 2006). On the social level, "net" 
symbolizes the complex living environment of modern people and there is a great deal of contradictions and conflicts. In language analysis, "net" is also a "predator" in nature. It is a trap, and chaos. People are tangled as the innumerable points on the network and cannot be separated. In terms of psychology, the "net" also symbolizes the narrow consciousness and cognitive range of the individual. In Under the Net, the main character lives in the net set by himself and explores and judges the world with his own sight. On the other hand, Murdoch is deeply influenced by Picture Theory of Language (Gale Group, 1983) proposed by Wittgenstein. The "net" also symbolizes the concepts and ideas of language construction, which is the net of words and language. She asked us to think how to use language to describe the world, how to truly react to the complex world and reveal the truth.

\section{Conclusion}

By reading Murdoch's work, we can find out her skepticism about language (Heusel, 1995). Most of the protagonists she created are self-centered. The attitude towards language inevitably reflects her general view of art: if language is easily falsified and becomes a lie then art will be the same (Byatt, 1976). In The Sovereignty of Good, subjective consciousness such as fantasy and delusion has an invisible connection with human speech talent. Fantasy refers to the lost state of people in the chaos of daydreaming (Plato defined it as Eikasia. It is the inability to perceive whether a perception is an image of something else. It therefore prevents us from perceiving that a dream or memory or a reflection in a mirror is not reality as such). Delusion is to control others through suggestive language (Murdoch, 1997). Thus, Murdoch's description of “goodness” is: “Goodness is rare and difficult to describe". Maybe we can only have the goodness of receiving good truths in simple people, such as the dedicated mother with vague words but is selflessness (Knight, 1957).

In Murdoch's writing, the theme of goodness often appears. Only through fighting the confusion and self-evolution, can we reach the "good" situation. Her works are extremely philosophical and strive to propose a rescue strategy for social morality and social contradictions. As a writer, Alice Murdoch is undoubtedly one of the brave women who has issued the strong voice of the times and dare to explore social ethics, and has drawn a path of goodness and truth-seeking for the society.

\section{Conflicts of Interest}

The authors declare no conflicts of interest regarding the publication of this paper.

\section{References}

Byatt, A. S. (1976). Iris Murdoch (p. 10). London

Gale Group (1983). Contemporary Authors, New Revision Series (p. 375). Vol. 8, Lon- 
don.

He, W. W. (2009). The Goodness, Love and Art-Study on the Morality Theme of Murdoch's Novel. Foreign Literature Review, No. 3, 41-54.

Heusel, B. S. (1995). Patterned Aimlessness: Iris Murdoch's Novels of the 1970s and the 1980 s (p. 13). London.

Hou, W. R., \& He, W. W. (1998). Literary Performance of Philosophy: A Study on the Novel Creation of Iris Murdoch. Journal of Shanghai International Studies University, No. 5, 1-7.

Knight, E. (1957). Murdoch I. "Existentialist Bite”. Review of Literature Considered as Philosophy (68-69).

Liu, F. T. (1985). New Modern Western Philosophy. Beijing: People's Publishing House.

Murdoch, I. (1997). Against Dryness (pp. 24-26). London: Chatto \& Windus Ltd.

Murdock, I. (1960). Under the Net. London: Penguin Books.

Shen, Z. M. (2005). Aymard Sartre's Anthology, Volume 5, Drama (I) (p. 142). Beijing: People's Literature Publishing House.

Wang, Y. H. (2006). Beyond Female Discourse, Going to the Realm of "Selfless"-Aesthetic Pursuit of Iris Murdoch's Novels, Also on "Under the Net". Foreign Literature, No. 4, $82-91$.

Wittgenstein (1992). Philosophy of Logic. Beijing: Business Press. (In English)

Wu, X. L. (2008). Empiricism and Rationalism in the History of Western Language during $16^{\text {th }}$ and $18^{\text {th }}$ Century Science and Technology Information. Science Teaching and Research, No. 21, 143-143.

Xu, C. W., Liu, F. T., Wang, K. Q. et al. (1982). Sartre and Existentialism (p. 61). Beijing: People's Publishing House.

Yin, Q. P. (1999). Treating Contemporary Novels-On Murdoch's View of Novels. Foreign Language and Foreign Language Teaching, No. 8, 44-46. 